\title{
Watermelon juice and aquatic exercises, their synergistic effect on some physical fitness and physiological variables in males and females volunteers
}

\author{
Jamal Shaker OMAR ${ }^{1 *(D)}$, Ahmad KHASATI ${ }^{2}$ (D) , Abdel Naser QADOUMI ${ }^{3}$ (D), \\ Mohammad QADOUMI 2 (D) , Nidal JARADAT 4 (D) \\ 1 Department of Physical Education, An-Najah National University, Nablus, Palestine. \\ 2 College of Science, Arab American University, Jenin, Palestine. \\ 3 Alistiqlal University, Jericho, Palestine \\ 4 Department of Pharmacy, Faculty of Medicine and Health Sciences, An-Najah National University, Nablus, \\ Palestine \\ * Corresponding Author. E-mail: shakerjammal@najah.edu (J.S.O); Tel. +00-97092347601
}

Received: 28 August 2018 / Revised: 16 January 2019 / Accepted: 29 January 2019

\begin{abstract}
During the last century there were significant changes in elucidating the role of functional foods on the human's health. Recently the global interest is focusing on the natural diets due to their important role on the physical and physiological performances. The current study aimed to evaluate the synergistic effect of watermelon juice and aquatic exercises on some physical fitness and physiological variables depending on experimental and reference groups. Thirty-six students (18 males and 18 females) in the age (19-22) from the Physical Education Department at An-Najah National University volunteered to participate in the experiment. An anthropometric measurement was performed alongside with specific medical examinations to determine the effect of both aquatic and watermelon juice and aquatic exercises alone on some physical fitness and physiological variables. The results show that both, watermelon juice and aquatic exercises, revealed statistically significant differences at $p$ value $<0.05$ compared with aquatic exercises alone. In case of gender, male and female the F-values were found significant at $\mathrm{p}<0.05$ for the variables (endurance, sprint $30 \mathrm{~m}$, sit up, total cholesterol, high density lipoproteins). Furthermore, these findings indicated that male students were better than female students in (endurance, sprint $30 \mathrm{~m}$, sit up test, and total cholesterol); in contrast female students had more high-density lipoproteins than male students. The synergistic effects of watermelon juice with aqua exercises improved the performance and physiological variables for the experimental group.
\end{abstract}

KEYWORDS: Watermelon; aqua exercises; performance; physiological variables.

\section{INTRODUCTION}

The usage of drugs and techniques by the world's top athletes to enhance performance has been a tenacious issue in world sporting events for nearly more than four decades and this behavior dates back to the Ancient Greeks who used mushrooms, ginseng root, and opium to enhance their athletic prowess. Therefore, some athletes consume drugs for improving their performance. However, the majority of individuals utilizing these substances are considered from recreational athletes kind of sports e.g., weightlifters and bodybuilders, to improve overall strength and personal appearance [1]. It is presumed that most, if not all, drugs have potential short-term and/or long-term side effects. Unfortunately, it is difficult to confirm such effects directly through studies as it would be unethical to give dosages as high as those used by athletes for performance enhancement [2]. Knowledge about side effects may be approved from empirical observation, reports of admitted users and effects in patients prescribed such agents for medical conditions [3-5]. Nowadays, scientists return back to natural products as a safer alternative to drugs. Watermelon contains important elements, acids, vitamins and simple carbohydrates, which all of them have been proven to have beneficial effects in humans [6]. Beneficial ingredients in watermelon are known as phyto-nutrients. These biological active natural compounds are able to metabolize in the human body to enhance physiological and biochemical processes that will improve human body performances. L-Citrulline, which

How to cite this article: Omar JS, Khasati A, Quadoumi AN, Qadoumi M, Jaradati N. Watermelon juice and aquatic exercises, their synergistic effect on some physical fitness and physiological variables in males and females volunteers. J Res Pharm. 2019; 23(3): 387-394. 
exists in watermelon, is a ubiquitous amino acid in mammals and closely related to L-arginine. It is a known stimulator of nitric oxide (NO) production [7]. Which is a key element for various biological processes within human body which travels freely from one cell to another assisting in a variety of biological functions and can act as an intracellular messenger, a hormone, and a neurotransmitter. Body builders or those who perform rigorous physical activities need a higher amount of NO, as it allows for an increase in blood flow while building muscles. In addition, watermelon has a diuretic effect and considered homeopathic treatment of renal failure disease and its use for dialysis became wide spread $[8,9]$.

In the kidney, vascular endothelium, and other tissues, L-citrulline can be readily converted to Larginine, which is the main precursor of NO, via nitric oxide synthase (NOS) activity [10, 11]. It was found that oral L-arginine supplementation decreases brachial blood pressure via improved endothelial NO production in adults with prehypertension and hypertension [12, 13]. Recently, watermelon juice has a positive reputation amongst athletes and scientists, due to its ability to relieve post-exercises muscle soreness [14].

The naturally occurring chemicals found in the watermelon fruit accelerated lactic acid removal, which enables better physical performances. Accordingly, athletes can carry out more intense training and able to recover faster after each workout. A report which was published in the Journal of Agricultural and Food Chemistry, attributed watermelon's effects to the amino acid L-citrulline [14]. This acid is an essential compound in the production of NO, a gas that widens the blood vessels, and previous studies have also found that a daily dose of watermelon could lower blood pressure, reducing the risk of a stroke or heart attack.

In addition to drugs and natural functional foods, such as watermelon, aqua fitness also has significant effects on the human body in many capacities. These include effects on joint flexibility $[15,16]$, functional ability [17], muscle strength [18], and aerobic fitness [15]. Aquatic therapy is becoming more popular due to the therapeutic benefits of water. During exercise, the demand for oxygen and energy substrates is elevated in active skeletal muscle. To meet increased demand, blood flow to working musculature is increased. NO has been identified as an important contributor to the vasodilatation observed with exercise [19]. It is known that NO synthesis occurs via at least two physiological pathways: The nitric oxide synthase (NOS) dependent and NOS independent pathway. In the former pathway the NO production includes a series of reactions oxidizing L-arginine to L-citrulline and NO [20]. Given their importance in the NOS-dependent pathway, a number of studies have investigated the effects of arginine and L-citrulline-based supplements on exercise performance [21-23]. This study aimed to evaluate for the first time the synergistic effect of watermelon juice with aquatic exercises with the pre and post tests on some physical fitness and physiological variables in favor of posttests for both genders and subgroups.

\section{RESULTS}

This study conducted for eight weeks of watermelon juice supplementation and aquatic exercises on 36 participants to evaluate their effects on some physical fitness and physiological variables. All the results in Table 1A and Table 1B indicated that there were statistically significant differences between the pre and post-tests of some physical fitness and physiological variables in favor of post-tests for both genders and subgroups. The tow way ANOVA results in table 2 revealed that there were statistically significant differences at $\mathrm{p} \leq 0.05$ according to gender, group, and interaction. In case of gender (male \& female), there were significant differences at $\mathrm{p} \leq 0.05$ in the variables of (endurance, sprint $30 \mathrm{~m}$, sit up, TC, and HDL), and no significant differences were noticed for the other variables. Furthermore, these findings indicated that male students were better than female students in (endurance, sprint $30 \mathrm{~m}$, sit up test, and TC) variables; in contrast female students had greater HDL than male students (Figure 1). In case of group (experimental \& reference) there were significant differences at $\mathrm{p} \leq 0.05$ for the variables of (endurance, sprint $30 \mathrm{~m}, \mathrm{TC}, \mathrm{TG}$, HDL, and LDL), and no significant differences were seen for the flexibility and sit up test variables. The experimental group (with regard to both genders) was physically and physiologically better than the reference group (Figure 2). 


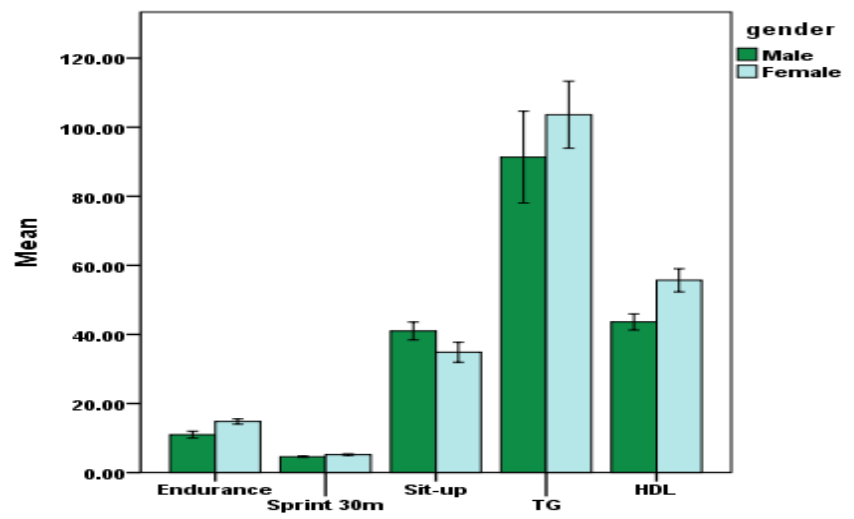

Figure 1. The differences in post-tests according to the gender variable.

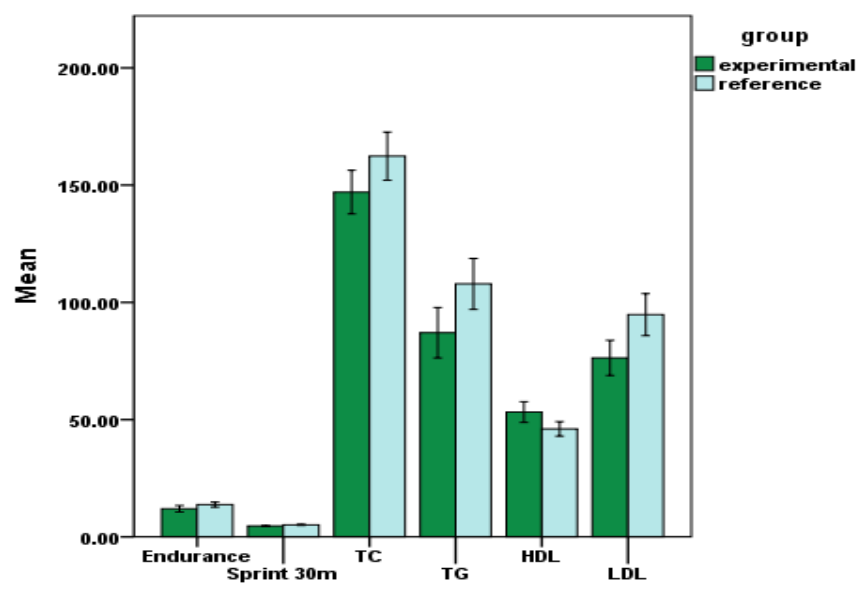

Figure 2. The differences in post-tests according to the group variable.

In case of interaction (gender* group), there were statistically significant differences at $p \leq 0.05$ for the sit up test and TG variables. In sit up test, male students (experimental group) were better than female students of both groups and male students in reference group. In addition, the performance of male and female students (reference group) was greater than female students (experimental group), no significant difference was found between male and female students in reference group (Figure 3). Moreover, male students (experimental group) were better than female students of both groups and male students in reference group for (TG) variable, and no significant differences in the other comparisons (Figure 4).

Table 1A. The synergistic effect of watermelon juice and aquatic exercises on some physical fitness and physiological variables for the experimental group.

\begin{tabular}{ccccc}
\hline \multirow{2}{*}{$\begin{array}{c}\text { Physical fitness and } \\
\text { physiological } \\
\text { variables }\end{array}$} & \multicolumn{2}{c}{ Female students } & $\mathbf{N = 9}$ & \multicolumn{2}{c}{ Male students } & N=9 \\
\cline { 2 - 5 } & $\mathbf{M} \pm$ SD & Post & Pre & Post \\
\cline { 2 - 5 } & $16.01 \pm 1.74$ & $14.22 \pm 1.71^{*}$ & $11.69 \pm 1.29$ & M \pm SD \\
\hline Endurance (min) & $10.33 \pm 9.04$ & $18.44 \pm 9.13^{*}$ & $8.44 \pm 9.12$ & $17 \pm 7.01^{*}$ \\
Flexibility (cm) & $5.88 \pm 0.43$ & $4.91 \pm 0.42^{*}$ & $5.10 \pm 0.45$ & $4.37 \pm 0.25^{*}$ \\
Sprint (30m/s) & $24.22 \pm 7.82$ & $32 \pm 4.12^{*}$ & $35 \pm 4.35$ & $43.44 \pm 4.58^{*}$ \\
Sit up (times/min) & $183.38 \pm 15.95$ & $155 \pm 14.45^{*}$ & $167.19 \pm 16.53$ & $139.01 \pm 19.71^{*}$ \\
TC (mg/dl) & $146.26 \pm 36.06$ & $102.02 \pm 18.05^{*}$ & $125.21 \pm 34.5$ & $72.09 \pm 12.72^{*}$ \\
TG (mg/dl) & $45.37 \pm 5.08$ & $59.48 \pm 7.97^{*}$ & $37.52 \pm 3.18$ & $47.02 \pm 4.24^{*}$ \\
HDL (mg/dl) & $108.75 \pm 17.66$ & $75.11 \pm 14.20^{*}$ & $104.62 \pm 16.16$ & $77.56 \pm 16.65^{*}$ \\
LDL (mg/dl)
\end{tabular}

Note values are $\mathrm{M} \pm \mathrm{SD}=$ mean \pm standard deviation; $\mathrm{TC}=$ Total Cholesterol; TG= Triglycerides; HDL=High Density Lipoproteins; LDL= Low Density Lipoproteins; *Significant effect (pre vs. post) differences at $p \leq 0.05$. 
Table 1B. The effect of aquatic exercises on some physical fitness and physiological variables for the reference group.

\begin{tabular}{ccccc}
\hline \multirow{2}{*}{$\begin{array}{c}\text { Physical fitness and } \\
\text { physiological variables }\end{array}$} & \multicolumn{2}{c}{ Female students } & $\mathbf{N}=\mathbf{9}$ & \multicolumn{2}{c}{ Male students } & N=9 \\
\cline { 2 - 5 } & Pre & Post & Pre & Post \\
\cline { 2 - 5 } & $\mathbf{M} \pm$ SD & M \pm SD & M \pm SD & M \pm SD \\
\hline Endurance(min) & $16.34 \pm 1.02$ & $15.32 \pm 1.07^{*}$ & $13.19 \pm 1.86$ & $12.20 \pm 1.88^{*}$ \\
Flexibility(cm) & $5.55 \pm 5.05$ & $15.22 \pm 4.52^{*}$ & $5.88 \pm 3.3$ & $14.44 \pm 3.32^{*}$ \\
Sprint(30m/s) & $5.90 \pm 0.61$ & $5.44 \pm 0.44^{*}$ & $5.11 \pm 0.43$ & $4.83 \pm 0.36^{*}$ \\
Sit-up(times/min) & $29 \pm 7.01$ & $37.66 \pm 6.02^{*}$ & $33.44 \pm 4.69$ & $38.55 \pm 4.87^{*}$ \\
TC (mg/dl) & $190.99 \pm 25.01$ & $168.65 \pm 25.37^{*}$ & $179.69 \pm 9.83$ & $156.42 \pm 13.45^{*}$ \\
TG (mg/dl) & $172.40 \pm 39.17$ & $105.18 \pm 21.88^{*}$ & $144.47 \pm 25.85$ & $110.57 \pm 22.85^{*}$ \\
HDL (mg/dl) & $43.18 \pm 4.65$ & $51.88 \pm 1.88^{*}$ & $35.90 \pm 2.62$ & $40.2 \pm 1.35^{*}$ \\
LDL (mg/dl) & $113.32 \pm 23.23$ & $95.43 \pm 23.30^{*}$ & $114.89 \pm 10.58$ & $94.11 \pm 12.25^{*}$ \\
\hline
\end{tabular}

Note values $\mathrm{M} \pm \mathrm{SD}=$ mean \pm standard deviation; $\mathrm{TC}=$ Total Cholesterol; $\mathrm{TG}=$ Triglycerides; HDL=High Density

Lipoproteins; LDL= Low Density Lipoproteins; *Significant effect (pre vs. post) differences at $\mathrm{p} \leq 0.05$.

Table 2 Two-way ANOVA for the differences in the post tests of some physical fitness and physiological variables according to gender, group and interaction (gender* group).

\begin{tabular}{|c|c|c|c|c|c|c|c|c|c|}
\hline \multirow{3}{*}{$\begin{array}{c}\text { Physical fitness } \\
\text { and } \\
\text { physiological } \\
\text { variables }\end{array}$} & \multicolumn{2}{|c|}{$\begin{array}{l}\text { Experimental } \\
\text { Group }\end{array}$} & \multicolumn{2}{|c|}{ Reference Group } & \multicolumn{5}{|c|}{ Sources of Variation } \\
\hline & \multirow{2}{*}{$\begin{array}{c}\text { Male } \\
M \pm S D\end{array}$} & \multirow{2}{*}{$\begin{array}{c}\text { Female } \\
\mathrm{M} \pm S D\end{array}$} & \multirow{2}{*}{$\begin{array}{c}\text { Male } \\
\mathrm{M} \pm \mathrm{SD}\end{array}$} & \multirow{2}{*}{$\begin{array}{c}\text { Female } \\
M \pm S D\end{array}$} & \multicolumn{2}{|c|}{ Gender (total) } & \multicolumn{2}{|c|}{ Group (total) } & \multirow{2}{*}{$\begin{array}{c}\text { Interaction } \\
\text { P-value }\end{array}$} \\
\hline & & & & & $\begin{array}{c}\text { Male } \\
\mathrm{M} \pm S D\end{array}$ & $\begin{array}{c}\text { Female } \\
M \pm S D\end{array}$ & $\underset{M \pm S D}{\operatorname{Exp}}$ & $\begin{array}{c}\text { Ref } \\
M \pm S D\end{array}$ & \\
\hline Endurance(min) & $\begin{array}{c}9.74 \pm \\
1.26\end{array}$ & $\begin{array}{c}14.22 \pm \\
1.71\end{array}$ & $\begin{array}{c}12.20 \pm \\
1.88\end{array}$ & $\begin{array}{c}15.32 \pm \\
1.07\end{array}$ & $\begin{array}{c}10.97 \pm \\
2.01^{*}\end{array}$ & $\begin{array}{c}14.77 \pm \\
1.50\end{array}$ & $\begin{array}{c}11.98 \pm \\
2.73^{*}\end{array}$ & $\begin{array}{c}13.76 \pm \\
2.19\end{array}$ & 0.197 \\
\hline Flexibility $(\mathrm{cm})$ & $\begin{array}{l}17 \pm \\
7.01\end{array}$ & $\begin{array}{c}18.44 \pm \\
9.13\end{array}$ & $\begin{array}{c}14.44 \pm \\
3.32\end{array}$ & $\begin{array}{c}15.22 \pm \\
4.52\end{array}$ & $\begin{array}{c}15.72 \pm \\
5.48\end{array}$ & $\begin{array}{c}16.83 \pm \\
7.18\end{array}$ & $\begin{array}{c}17.72 \pm \\
7.93\end{array}$ & $\begin{array}{c}14.83 \pm \\
3.87\end{array}$ & 0.877 \\
\hline Sprint $(30 \mathrm{~m} / \mathrm{s})$ & $\begin{array}{c}4.37 \pm \\
0.26\end{array}$ & $\begin{array}{l}4.91 \pm \\
0.42\end{array}$ & $\begin{array}{c}4.83 \pm \\
0.36\end{array}$ & $\begin{array}{c}5.44 \pm \\
0.44\end{array}$ & $\begin{array}{l}4.60 \pm \\
0.38^{*}\end{array}$ & $\begin{array}{c}5.17 \pm \\
0.50\end{array}$ & $\begin{array}{l}4.64 \pm \\
0.43^{*}\end{array}$ & $\begin{array}{c}5.13 \pm \\
0.50\end{array}$ & 0.784 \\
\hline $\begin{array}{c}\text { Sit up } \\
\text { (times/min) }\end{array}$ & $\begin{array}{c}43.44 \pm \\
4.58\end{array}$ & $\begin{array}{l}32 \pm \\
4.12\end{array}$ & $\begin{array}{c}38.55 \pm \\
4.87\end{array}$ & $\begin{array}{c}37.66 \pm \\
6.02\end{array}$ & $\begin{array}{c}41 \pm \\
5.23^{*}\end{array}$ & $\begin{array}{c}34.8 \pm \\
5.79\end{array}$ & $\begin{array}{c}37.72 \pm \\
7.25\end{array}$ & $\begin{array}{c}38.11 \pm \\
5.33\end{array}$ & $0.003^{*}$ \\
\hline $\mathrm{TC}(\mathrm{mg} / \mathrm{dl})$ & $\begin{array}{c}139.01 \pm \\
19.71\end{array}$ & $\begin{array}{l}155 \pm \\
14.45\end{array}$ & $\begin{array}{c}156.42 \pm \\
13.45\end{array}$ & $\begin{array}{c}168.35 \pm \\
25.37\end{array}$ & $\begin{array}{c}147.72 \pm \\
18.66^{*}\end{array}$ & $\begin{array}{c}161.67 \pm \\
21.17\end{array}$ & $\begin{array}{c}147 \pm \\
18.68^{*}\end{array}$ & $\begin{array}{c}162.38 \pm \\
20.63\end{array}$ & 0.748 \\
\hline TG (mg/dl) & $\begin{array}{c}72.09 \pm \\
12.72\end{array}$ & $\begin{array}{c}102.02 \pm \\
18.05\end{array}$ & $\begin{array}{c}110.57 \pm \\
22.85\end{array}$ & $\begin{array}{c}105.18 \pm \\
21.88\end{array}$ & $\begin{array}{c}91.33 \pm \\
26.71\end{array}$ & $\begin{array}{c}103.60 \pm \\
19.52\end{array}$ & $\begin{array}{l}87.06 \pm \\
21.60^{*}\end{array}$ & $\begin{array}{c}107.87 \pm \\
21.88\end{array}$ & $0.010^{*}$ \\
\hline HDL (mg/dl) & $\begin{array}{c}47.02 \pm \\
4.24\end{array}$ & $\begin{array}{c}59.48 \pm \\
7.79\end{array}$ & $\begin{array}{c}40.20 \pm \\
1.30\end{array}$ & $\begin{array}{c}51.88 \pm \\
1.88\end{array}$ & $\begin{array}{c}43.61 \pm \\
4.65\end{array}$ & $\begin{array}{c}55.68 \pm \\
6.74^{*}\end{array}$ & $\begin{array}{c}53.25 \pm \\
8.84^{*}\end{array}$ & $\begin{array}{c}46.04 \pm \\
6.22\end{array}$ & 0.800 \\
\hline LDL (mg/dl) & $\begin{array}{c}77.56 \pm \\
16.65\end{array}$ & $\begin{array}{c}75.11 \pm \\
14.20\end{array}$ & $\begin{array}{c}94.11 \pm \\
12.25\end{array}$ & $\begin{array}{c}95.34 \pm \\
23.30\end{array}$ & $\begin{array}{c}85.84 \pm \\
16.54\end{array}$ & $\begin{array}{c}85.27 \pm \\
21.44\end{array}$ & $\begin{array}{l}76.34 \pm \\
15.06^{*}\end{array}$ & $\begin{array}{c}94.77 \pm \\
16.07\end{array}$ & 0.743 \\
\hline
\end{tabular}

Note values is $\mathrm{M} \pm \mathrm{SD}=$ mean \pm standard deviation; total $=$ male and female together; $\mathrm{TC}=$ Total Cholesterol; TG=Triglycerides; HDL=High Density Lipoproteins; LDL= Low Density Lipoproteins; *Significant differences at $\mathrm{p} \leq$ 0.05 .

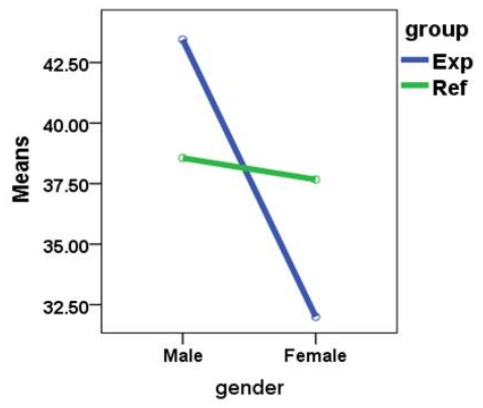

Figure 3. The interaction (gender* group) in sit up post-test.

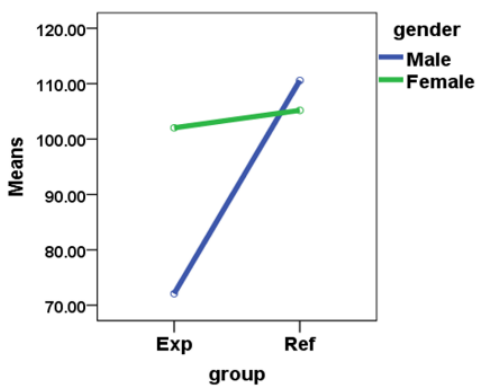

Figure 4. The interaction (gender* group) in TG post-test. 


\section{DISCUSSION}

From the ancient times, Water has been used for cleansing and religious means purposes specially among the Greeks, Egyptians, and Romans, and the fathers of healing, Pythagoras (B.C. 530) and Hippocrates (B.C. 460), used water with friction and rubbing for the treatment of rheumatism and gout [24, 25]. The physical properties of water may provide increased in relaxation, ease of movement, resistance, and support, with the added benefit of lower impact forces and pain levels [26, 27]. Aquatic exercises may even give individuals a better workout, indicating a higher amount of oxygen consumption during aquatic treatment. Due to the added benefits of water, many forms of aquatic therapy are now existing. Each mode of aquatic therapy and exercise introduces a variety of treatment and rehabilitative exercise programs [28]. The name for the L-citrulline amino acid is derived from the Latin word for watermelon (Citrullus) from which it was first extracted. Although L-citrulline is a component of a number of different foods, but watermelon juice is a primary source of L-citrulline which contains about $2.33 \mathrm{~g}$ of L-citrulline per $\mathrm{L}$ of unpasteurized juice [21]. Chronic supplementation with L-citrulline malate has been shown to enhance skeletal muscle power output in concert with a greater oxidative energy turnover and a lower $\mathrm{pH}$-to-power ratio and a lower ATP cost of muscle force production [29]. In a study which was conducted by Bailey et al., found that L-Citrulline supplementation improved $\mathrm{O}_{2}$ uptake kinetics and high-intensity exercise performance in humans [30]. In addition to that, it was approved that watermelon is rich source of many antioxidants such as $\beta$-carotene and lycopene which may increase nitric oxide bioavailability since they have been shown to blunt the scavenging of nitric oxide by superoxide [31]. It has also been reported by Tarazona et al. and Cutrufello et al., that ingestion of watermelon juice can attenuate muscle soreness after completing intense exercise [14, 32]. In fact, watermelon increases blood flow and reduces blood pressure by the action of L-citrulline on the blood vessels which expands them to improve blood flow and reduce blood pressure [33]. The NO is a biologically active substance produced through the conversion of L-arginine to L-citrulline via a $\mathrm{Ca}^{2+}$-dependent nitric oxide synthase (NOS) or a $\mathrm{Ca}^{2+}$-independent nitric oxide synthase (iNOS) which decreased muscle soreness and this leads to increase performance [34]. However, those results are consistent with other research which found that supplementation with amino acids like L-citrulline helps to improve athletic performance and achieve faster recovery [35]. However, Perez-Guisado and Jakeman found that citrulline malate ( $8 \mathrm{~g} /$ day) enhances athletic anaerobic performance and relieves muscle soreness [36]. Taken together all these facts, these observations suggest that watermelon juice could be a nitric oxide precursor which can be used to improve muscles performances and reduced muscles soreness. Acute and chronic exercise is known to alter blood lipid antioxidant profiles [37] and, incidentally, subjects who participate in greater amounts of exercise have raised lipid antioxidants compared to sedentary controls [38]. The obtained results showed the significant differences between the pre and post-tests of some physical fitness and physiological variables in favor of post-tests of both genders and subgroups. Furthermore, these findings indicated that male students were better than female students in endurance, sprint $30 \mathrm{~m}$, sit up test, and TC; in contrast with female students who had more HDL than male students. In the case of the group (experimental \& control) the F-values were found significant at $\mathrm{p}<0.05$ for the variables [endurance (min), sprint $(30 \mathrm{~m} / \mathrm{s}), \mathrm{TC}, \mathrm{TG}, \mathrm{HDL}, \mathrm{LDL}$, and no significant differences at $\mathrm{p}$ value $<0.05$ were seen for the flexibility $(\mathrm{cm})$ and sit up (times/min) test variables. In the case of interaction (gender* group), the F-values were found significant at $\mathrm{p}<0.05$ for the sit up test and TG variables. In sit up test, male students (experimental group) were better than female students of both groups and male students in control group. In addition, the performance of male and female students (control group) was greater than female students (experimental group), and no significant difference was found between male and female students in control.

Finally, male students (experimental group) were better than female students of both groups and male students in control group for (TG) variable and no significant differences in the other comparisons.

Further research should be concentrated on the relation between the doses of watermelon supplementation and aqua exercises to increase to maximum range the performance and humans' physiological variables.

\section{CONCLUSION}

This study showed that the synergistic effects of watermelon juice with aqua exercises and aquatic exercises alone improved athletic performance and physiological variables. Moreover, the obtained results showed that there were statistically significant differences between the pre and post-tests of some physical fitness and physiological variables in favor of post-tests for both genders and subgroups. This may be 
attributed to the chemical constituents of watermelon juice such as L-citrulline and the reduced effort of the muscle in aqua systems.

\section{MATERIALS AND METHODS}

Thirty-six students (18 males and 18 females) in the age range of 19 to 22, from the Physical Education Department, at An-Najah National University volunteered to participate in the experiment. The participants were not competitive athletes, but they participated regularly in different sports. The study was approved by the Ethical Committee of the An-Najah National University/Palestine. All of the study details were explained to the participants, who also gave their written consent. Participants completed a questionnaire about their personal history of health and diseases. Furthermore, an anthropometric evaluation was performed according to the International Society for the Advancement of Kinan thropometry (ISAK) [39]. These evaluations, alongside with medical examinations were used to determine the inclusion or exclusion criteria. These parameters were normal in all participants, who were not taking any medication or suffering from injuries that could interfere with their athletic performance in water.

Fresh watermelon juice was prepared from seedless watermelons purchased at a local supermarket (Motawe, Rafedia Str., Nablus-Palestine), the watermelon juice was prepared as described in Collins et al. [40]. The watermelon flesh was separated from the rind and liquefied using a juicer (Moulinex, Depose type 241). Then the participants of the experimental group were supplemented with $250 \mathrm{ml}$ watermelon juice two hours before the exercise. Two groups were included in this study, first group (9 males and 9 females) consumed fresh water melon juice with aquatic exercises and the second group only performed traditional aquatic exercises which considered a control group.

The studied two groups (all exercise participants) received a 1-hour aquatic exercise class 3 days a week on alternative days for 8 weeks from May 20 to July 20, 2015. The physical fitness variables included endurance, flexibility, sprint $30 \mathrm{~m}$ and sit-up. These variables were separately and scientifically measured before and after the training program, and after 10 minutes of warm-up. The endurance was evaluated by using cooper 1.5-mile run/walk test. The participants were instructed to complete the distance as quickly as possible and the time was recorded in minutes and seconds by using a stopwatch. The flexibility was measured by using sitting trunk forward flexion, the participants were asked to remove their shoes and sit on the ground with their feet together. With the command "start", they stretched both of their hands and bent their upper bodies to allow the middle fingers of both their hands to reach and slowly push the instrument. The students were asked not to bend their knees as they performed the test. The test was repeated twice for each student and the better scores were then recorded in centimeters. Sprint 30-meter test was used to evaluate the ability of participants to efficiently and effectively build up acceleration and reach the maximum speed. This test requires the participant to run as fast as possible over 30 meter after starting from standing position. The test was repeated twice for each participant and the better performance was recorded in seconds. Sit up test requires the participant to perform as many as sit-ups as possible during one minute. The participants were asked to put their legs apart by $30 \mathrm{~cm}$ with their legs bent at a right angle, as they lied on their backs on the mat without the fingers of both their hands laced behind their heads. With the command "start", they raised themselves, making both of their elbows touch their knees. The number of corrected times was recorded.

Blood samples (serum) of the participants were analyzed for Triglycerides (TG), Cholesterol (CT), High Density Lipoproteins (HDL) and Low-Density Lipoproteins (LDL) using closed system biochemistry analyzer (Roche-HitacheCopus, C311), in the laboratories of Public Health Division, Faculty of Medicine and Health sciences, An-Najah National University.

\subsection{Data analysis}

Means and standard deviations were used as descriptive statistics. Differences between pre and post tests were treated by using paired $t$ test for both genders and subgroups. Tow-way ANOVA analysis of variance was applied to determine the differences in post-tests according to gender, group and interaction. Data was analyzed using Statistical Package for Social Sciences (SPSS) version 20. The significance level was fixed at at $p \leq 0.05$ for all statistics. The sample was normally distributed and no significant differences were separately found in pre-tests between males (Exp vs. Ref) and females (Exp vs. Ref). 
Acknowledgements: The authors would like to thank Department of Physical Education of An-Najah National University. Also, the authors greatly acknowledge Department of Chemistry of Arab American University for its contribution.

Author contributions: Concept - J.O; Design - J.S.; Supervision - J.O., A.K.; Materials - J.O., A.K, M.Q.; Data Collection and/or Processing - J.O., A. K., M. Q., A. Q.; Analysis and/or Interpretation - M. Q, A. Q, N.J.; Literature Search N. J.; Writing - A.K, A. Q., N. J; Critical Reviews - J.O., A.K, M.Q., A.Q., N. J.

Conflict of interest statement: The authors declared no conflict of interest.

\section{REFERENCES}

[1] Parkinson AB, Evans NA. Anabolic androgenic steroids: a survey of 500 users. Med Sci Sports Exerc. 2006;38(4):644651. [CrossRef]

[2] Baron DA, Reardon CL, Baron SH. Clinical sports psychiatry: an international perspective. John Wiley \& Sons; UK 2013.

[3] Koshy KM, Griswold E, Schneeberger EE. Interstitial nephritis in a patient taking creatine. N Engl J Med. 1999;340(10):814-815. [CrossRef]

[4] Edmunds JW, Jayapalan S, DiMarco NM, Saboorian H, Aukema HM. Creatine supplementation increases renal disease progression in Han: SPRD-cy rats. Am J Kidney Dis. 2001;37:73-78. [CrossRef]

[5] Saugy M, Avois L, Saudan C, Robinson N, Giroud C. Cannabis and sport. Br J Sports Med. 2006;40(1):13-15. [CrossRef]

[6] Bansal V, Rodriguez P, Wu G, Eichler DC. Citrulline can preserve proliferation and prevent the loss of CD3 $\zeta$ chain under conditions of low arginine. J Parenter Enteral Nutr. 2004;28(6):423-430. [CrossRef]

[7] Bredt DS, Snyder SH. Isolation of nitric oxide synthetase, a calmodulin-requiring enzyme. Proc Natl Acad Sci. 1990;87(2):682-685. [CrossRef]

[8] Gul S, Rashid Z, Sarwer G. Citrullus lanatus (watermelon) as diuretic agent: An in vivo investigation on mice. Am J Drug Deliv Ther. 2014;1(4):89-92. [CrossRef]

[9] Pljesa S, Golubovic G, Tomasevic R, Markovic R, Perunicic G. “Watermelon stomach” in patients on chronic hemodialysis. Ren Fail. 2005;27(5):643-646. [CrossRef]

[10] Palloshi A, Fragasso G, Piatti P, Monti LD, Setola E. Effect of oral L-arginine on blood pressure and symptoms and endothelial function in patients with systemic hypertension, positive exercise tests, and normal coronary arteries. Am J Cardiol. 2004;93(7):933-935. [CrossRef]

[11] Solomonson LP, Flam BR, Pendleton LC, Goodwin BL, Eichler DC. The caveolar nitric oxide synthase/arginine regeneration system for NO production in endothelial cells. J Exp Biol. 2003;206(12):2083-2087. [CrossRef]

[12] Siani A, Pagano E, Iacone R, Iacoviello L, Scopacasa F, Strazzullo P. Blood pressure and metabolic changes during dietary L-arginine supplementation in humans. Am J Hypertens. 2000;13(5):547-551. [CrossRef]

[13] Martina V, Masha A, Gigliardi VR, Brocato L, Manzato E. Long-term N-acetylcysteine and L-arginine administration reduces endothelial activation and systolic blood pressure in hypertensive patients with type 2 diabetes. Diabetes Care. 2008;31(5):940-944. [CrossRef]

[14] Tarazona-Díaz MP, Alacid F, Carrasco M, Martínez I, Aguayo E. Watermelon juice: potential functional drink for sore muscle relief in athletes. J Agric Food Chem. 2013;61(31):7522-7528. [CrossRef]

[15] Wang TJ, Belza B, Elaine Thompson F, Whitney JD, Bennett K. Effects of aquatic exercise on flexibility, strength and aerobic fitness in adults with osteoarthritis of the hip or knee. J Adv Nurs. 2007;57(2):141-152. [CrossRef]

[16] Haag S, Schneider N, Mason DE, Tuncel J, Andersson IE, Peters EC, Burkhardt H, Holmdahl R. Identification of new citrulline-specific autoantibodies, which bind to human arthritic cartilage, by mass spectrometric analysis of citrullinated type ii collagen. Arthritis Rheumatol. 2014;66(6):1440-1449. [CrossRef]

[17] Templeton MS, Booth DL, O'Kelly WD. Effects of aquatic therapy on joint flexibility and functional ability in subjects with rheumatic disease. J Orthop Sports Phys Ther. 1996;23(6):376-381. [CrossRef]

[18] Taunton J, Rhodes E, Wolski L, Donelly M, Warren J, Elliot J, McFarlane L, Leslie J, Mitchell J, Lauridsen B. Effect of land-based and water-based fitness programs on the cardiovascular fitness, strength and flexibility of women aged 65-75 years. Gerontology. 1996;42(4):204-210. [CrossRef] 
[19] Hellsten Y, Nyberg M, Jensen LG, Mortensen SP. Vasodilator interactions in skeletal muscle blood flow regulation. J Physiol. 2012;590(24):6297-6305. [CrossRef]

[20] Bailey SJ, Vanhatalo A, Winyard PG, Jones AM. The nitrate-nitrite-nitric oxide pathway: Its role in human exercise physiology. Eur J Sport Sci. 2012;12(4):309-320. [CrossRef]

[21] Besco R, Sureda A, Tur JA, Pons A. The effect of nitric-oxide-related supplements on human performance. Sports Med. 2012;42(2):99-117. [CrossRef]

[22] Camic CL, Housh TJ, Zuniga JM, Hendrix RC, Mielke M. Effects of arginine-based supplements on the physical working capacity at the fatigue threshold. J Strength Cond Res. 2010;24(5):1306-1312. [CrossRef]

[23] Hickner RC, Tanner CJ, Evans CA, Clark PD, Haddock A, Fortune C. L-citrulline reduces time to exhaustion and insulin response to a graded exercise test. Med Sci Sports Exerc 2006;38(4):660-666. [CrossRef]

[24] Mukarromah SB. Pengembangan Aquajogger sebagai Peluang Bisnis yang Prospektif Dibidang Olahraga Kebugaran. Media Ilmu Keolahragaan Indonesia. 2014;4(2):105-113. [CrossRef]

[25] Metcalfe RL. Life of Vincent Priessnitz, founder of hydropathy. Hardpress Publishing; USA 2012

[26] Barela AM, Duarte M. Biomechanical characteristics of elderly individuals walking on land and in water. J Electromyogr Kinesiol. 2008;18(3):446-454. [CrossRef]

[27] Hinman RS, Heywood SE, Day AR. Aquatic physical therapy for hip and knee osteoarthritis: results of a singleblind randomized controlled trial. Phys Ther. 2007;87(1):32-36. [CrossRef]

[28] Murray B, Kenney WL. Practical guide to exercise physiology. Human Kinetics; USA 2016.

[29] Bailey SJ, Blackwell JR, Williams E, Vanhatalo A, Wylie LJ, Winyard PG, Jones AM. Two weeks of watermelon juice supplementation improves nitric oxide bioavailability but not endurance exercise performance in humans. Nitric Oxide. 2016;59:10-20. [CrossRef]

[30] Bailey SJ, Blackwell JR, Lord T, Vanhatalo A, Winyard PG, Jones AM. L-citrulline supplementation improves O2 uptake kinetics and high-intensity exercise performance in humans. J Appl Physio. 2015;119(4):385-395. [CrossRef]

[31] Zhu CH, Gertz ER, Cai Y, Burri BJ. Consumption of canned citrus fruit meals increases human plasma $\beta$ cryptoxanthin concentration, whereas lycopene and $\beta$-carotene concentrations did not change in healthy adults. Nutr Res. 2016;36(7):679-688. [CrossRef]

[32] Cutrufello PT, Gadomski SJ, Zavorsky GS. The effect of L-citrulline and watermelon juice supplementation on anaerobic and aerobic exercise performance. J Sports Sci. 2015;33(14):1459-1466. [CrossRef]

[33] Figueroa A, Sanchez-Gonzalez MA, Perkins-Veazie PM, Arjmandi BH. Effects of watermelon supplementation on aortic blood pressure and wave reflection in individuals with prehypertension: a pilot study. Am J Hypertens. 2011;24(1):40-44. [CrossRef]

[34] Watson TA, MacDonald-Wicks LK, Garg ML. Oxidative stress and antioxidants in athletes undertaking regular exercise training. Int J Sport Nutr Exerc Metab. 2005;15(2):131-146. [CrossRef]

[35] Giannesini B, Le Fur Y, Cozzone PJ, Verleye M, Le Guern M-E, Bendahan D. Citrulline malate supplementation increases muscle efficiency in rat skeletal muscle. Eur J Pharmacol. 2011;667(1):100-104. [CrossRef]

[36] Pérez-Guisado J, Jakeman PM. Citrulline malate enhances athletic anaerobic performance and relieves muscle soreness. J Strength Cond Res. 2010;24(5):1215-1222. [CrossRef]

[37] Brites FD, Evelson PA, Christiansen MG, Nicol MF, Basílico MJ, Wikinski RW, Llesuy SF. Soccer players under regular training show oxidative stress but an improved plasma antioxidant status. Clin Sci. 1999;96(4):381-385. [CrossRef]

[38] Böger RH, Bode-Böger SM. The clinical pharmacology of L-arginine. Annu Rev Pharmacol Toxicol. 2001;41(1):7999. [CrossRef]

[39] Norton K, Whittingham N, Carter L, Kerr D, Gore C, Marfell-Jones M. Measurement techniques in anthropometry. New South Publishing; Sydney 1996.

[40] Collins JK, Wu G, Perkins-Veazie P, Spears K, Claypool PL, Baker RA. Watermelon consumption increases plasma arginine concentrations in adults. Nutrition. 2007;23(3):261-266. [CrossRef] 